\title{
Business Associations and the Developmental State in Korea The Case of the Machinery Industry in the 1960 and 1970s*
}

\author{
Seok-Jin Eom** and Jae-Young Choi***
}

\begin{abstract}
This research examines a way the Korean developmental state achieved a synergy between state and society for industrial development: business associations. In the machinery industry, a business association was involved in formulating industrial policy for promoting the machinery industry and in implementing policy programs such as the prohibition of the import of machinery made in foreign countries. The association also functioned as a channel through which information relevant to the industry was provided to government. The association had a professional staff and an internal governance structure that helped prevented rent seeking and encouraged synergy between public and private sector.
\end{abstract}

Keywords: business associations, developmental state, industrial policy, Korean economic growth in the 1960 and 1970s

\section{INTRODUCTION}

The industrial development and economic growth in South Korea (hereafter Korea) since the early 1960s have made it a favorite test case for every theory of development and pose enduring academic challenges to any social scientist interested in developmental studies. In the 1960 and 1970s, neoclassical economic explanations that emphasized the Korean government's fidelity to free market principles and its wisdom in adopting a minimalist role during the developmental process were dominant. Since the late 1980s, however, "developmental state" theorists have focused on policy capacity and state autonomy based on which the national government effec-

* This study was financially supported by Korea Development Institute (KDI) in Korea (20110724435-00).

** The corresponding author, Seok-Jin Eom is an associate professor in the Graduate School of Public Administration at Seoul National University. Email : sjum21@snu.ac.kr.

*** Jae-Young Choi is the secretary General in National Economic Advisory Council in Korea. Email : jaychoisw@naver.com.

Manuscript received July 17, 2017; out for review July 24, 2017; review completed October 22, 2017; accepted October 25, 2017.

The Korean Journal of Policy Studies, Vol. 32, No. 3 (2017), pp. 29-51.

(C) 2017 by the GSPA, Seoul National University 
tively intervened in the economy while also allowed a measure of independence with regard to control by local elites.

In spite of the different theoretical and empirical arguments among scholars, the importance of a growth-oriented relationship between government and business has been commonly emphasized in explaining industrial development in Korea. For example, Evans (1995) stresses the close relationship between the state and business through the concept of "embedded autonomy." The Korean developmental state, Evans posits, is "embedded in a concrete set of social ties" that link the state apparatuses to society and possesses "corporate coherence" that endows its apparatuses with "a certain kind of autonomy" that allows them to transcend the interests of social forces in the formulation of goals and strategies. The state, having developed extensive institutional channels connecting it to the private sector, is seen to be able to reach down into the economy to assist and encourage economic growth in a myriad of ways. The World Bank (1993, pp. 181-188) also maintains that high-performing Asian economies, including Korea, tend to have institutions such as deliberation councils that facilitate information transmission and cooperation between the private and the public sectors.

We share their views, but we also find some weaknesses in their analysis of the relationship between the Korean developmental state and businesses. First, previous research has not fully analyzed the variety of institutional mechanisms and organizations that mediate between the public and private sector. Evans, for example, maintains that "embeddedness under Park was much more "top down" affairs than the Japanese prototype, lacking the well-developed intermediary associations and focused on a small number of very large firms" (1995, p. 53). However, various intermediary organizations, such as the industrial associations that we explore here, have played an active role in Korea's development since the beginning. The Korean government has always promoted the organizing of business associations and institutionalized interactions with industry associations as a means of getting information and for purposes of formulating policy alternatives pertaining to industry and to enhance its policy implementation capability with a network of private actors.

Second, the previous research does not appear to fully explain the mechanisms for preventing the negative effects of networking between state and businesses and for achieving positive effects. The rent-seeking activities of special interests in the market tend to have a detrimental influence on the state capacity for industrial development (Doner \& Schneider, 2000; Schneider, 1998; Olson, 1997, p. 46). However, this has not proven to be the case in Korea; the close relationship between the state and business in Korea had not negatively impacted industrial development (World Bank, 1993, pp. 174-181). So the question is what mechanisms and governance structures 
of the business associations have contributed to preventing such detrimental influence and to achieving the synergy between the two? There are a number of researchers who have studied these business associations (Kim, 1997; Chu, 1994; Shin, 1991), but they do not provide detailed analysis their internal makeup such as the resources for carrying out their functions or their internal governance structures, which contribute to resolving conflicts of interest among their members and between businesses and government in Korea.

To fill these gaps in the scholarship, we decided to explore the role the Korea Association of Machinery Industry (KOAMI) played in Korea's development from the 1960s to 1970s. Because the Park Chung-hee administration made great efforts to promote the machinery industry with various policy programs, regarding it as critical for heavy-chemical industrialization, it provides a good case study that highlights the salient activities of the business association and the intense policy coordination among major industrial ministries in government. We analyzed the functions of the business association and its interaction with government, through which the government received information on the industry as well as policy proposals from businesses designed to enhance policy implementation capability. In addition, we analyzed the internal governance structure of the business association to see how it managed to control rent seeking.

Primary data sources for this study included the results of face-to-face interviews with former public officials involved in industrial policy making under the Park Chung-hee administration, the staff of industrial associations, as well as researchers and professors who have studied Korean economic development and industrial policy. Moreover, we examined a wealth of archival information including white papers, newspaper articles, academic papers, and government documents.

This paper is divided into five sections. In the next section, we review the theories on the contributions of business associations to industrial development in developing countries. In section three, we look at the industrial policy programs associated with the machinery industry in the 1960 and 1970s. In section four, we examine the activities of the business association in the machinery industry. In the concluding section, we summarize our findings and consider the theoretical and policy implications of these findings for developing countries. 


\section{BUSINESS ASSOCIATIONS IN A DEVELOPMENTAL CONTEXT}

\section{Definition of the Business Association and Its Functions}

Business associations are defined as "long-term organizations with formal statutes regulating membership and internal decision-making in which the members are individual business people, firms, or other associations that are not necessarily linked by ownership [such as is the case with Japan's keiretsu] or contractual ties" (Doner \& Schneider, 2000, p. 280). There are two ways business associations can contribute to economic performance in the context of developing countries (Doner \& Schneider, 2000). First, they can strengthen the overall functioning of markets by protecting property rights and by helping the government operate more effectively for industrial development. Business associations not only monitor government policy but also provide information and resources that help public officials formulate industrial policy. They also set the industrial policy agenda and mobilize resources for economic development such as money and information. In addition, business associations can contribute to the development of infrastructure by direct action as well as by putting indirect pressure on government officials.

Second, business associations can help in overcoming various types of market imperfections and coordination problems. This type of contribution involves direct coordination among firms to integrate interdependent production and investment decisions by maintaining macroeconomic stability by, for example, reducing inflation; ensuring horizontal coordination that helps control markets crucial to the profits of members; ensuring vertical coordination facilitating supply, price, and quality coordination between upstream and downstream parts of the value chain; reducing information costs; setting standards for export; and upgrading quality.

\section{Business Associations' Contributions to Economic Growth}

How do business associations contribute to building a relationship between government and business that is more growth oriented? In the context of the developing countries, two fundamental issues for sustainable industrial development have presented themselves. One is the need to build strong sets of institutions for protecting property rights, establishing vertical/horizontal coordination systems among businesses, and building contract enforcement mechanisms because this encourages collaboration between the state and society, rather than collusion or predation (Schneider \& Maxfield, 1997; Shirley, 2005). The other is the importance of establishing information channels between government and stakeholders in society and industry. In 
order to economize the transaction cost in policy making and to respond efficiently to the fast changes in the policy environment, the government must be open to receiving a wide range of information from businesses and stakeholders, including much that is uncomfortable and dissonant. If such communication channels have been put in place, then the government is likely to be in close communication with societal actors who possess information required for effective governing (Pierre \& Peters, 2005, p. 46).

The active mediation of business associations has helped tackle these fundamental issues in several ways (Schneider, 2015). First, as Lucas (1997) argues, compared to individuals, associations are less likely to engage in corrupt practices owing to their transparency. Business associations are by no means immune to corruption, but in a formal organization these abuses are easier to detect and are less likely to persist. For entrepreneurs, transparency offers the additional benefits of reducing the uncertainty of the economic environment and increasing confidence that competitors are not being given unfair concessions. Second, by representing collectivities, business associations are less susceptible to rent seeking. Associations aggregate interests and encourage entrepreneurs to address their problems in sectoral and systemic terms rather than individually. They define problems inclusively and generally rather than specifically. In the absence of business associations, entrepreneurs are more likely to respond to collective problems with adaptive and avoidance techniques such as bribery and clientelism.

For a business association to efficaciously perform its representative functions, its executive body should have autonomous power, professional expertise in the industry, and the ability to produce knowledge and data (indeed, an association's command over information is one of the most important of its tools). To achieve these goals, the executive body of a business association should be comprised of specialized functional organizations whose staff members are professionals and experts on the industry and business rather than a consultative group among member companies. Professional employees not only may have a long-term perspective that allows them to see beyond the short-term profits of the industry but also tend to have the motivation and perspective necessary to coordinate opposing parties (Coleman, 1988; de Vroom, 1985, pp. 129-130). In addition, specialization in an executive body and functional differentiation are essential to ensuring stability and self-regulation in business associations (Streeck, 1982, pp. 51-56). Building these capacities, of course, costs money. Therefore, a strong business association will usually have an ample operating budget, supported by donations from the government and/or dues from members. These diverse resources make the associations autonomous not only from its member firms but also from the government (Coleman, 1988, pp. 58-60). 
In addition, the strength of business associations relates to the extent of their monopoly and control over the industry. If associations are fragmented it is difficult to establish a unified business position on important issues as well as to solve free-rider problems. A decentralized system of business associations can be influential, but this influence is more likely to be exercised at the sectoral and regional levels; more centralized associations can exert influence at the national level. Moreover, more productive associations have high member density, the ability to provide valuable resources to their members, and internal mechanisms for mediating member interests (Doner \& Schneider, 2000, p. 271). ${ }^{1}$

\section{Literature Review on Business Associations}

The active role of business associations has been recognized as one of the important institutional elements for building the kind of state-business relationship that produces effective industrial policy and economic growth in developing countries. In practice, the number and the scale of business associations has grown dramatically in recent decades, and they are becoming influential actors in both national and international governance (Kuteesa \& Mawejje, 2016; Schneider, 2015; Irwin, 2015). Yet there is surprisingly little research on these organizations and so the extent of their organizational capacity and internal governance have not been fully appreciated(Marques, 2017). Furthermore, although the empirical literature offers numerous, isolated examples of productive activities by business associations, there is no scholarship that provides analytic frameworks for comparing associations across countries and regions (Doner \& Schneider, 2000).

To fill these gaps, some scholars such as Nadvi (1999), Lucas (1997), and Moore and Hamalai (1993) have tried compare the roles of business associations in developing countries. For example, Doner and Schneider (2000) analyze the activities of business associations in Latin American countries including Colombia, Brazil, Chile, and Mexico and East Asian countries including Thailand, Taiwan, Pakistan, and South Korea, seeking to identify common aspects of as well as factors that account for variations in their contribution to economic growth as well.

More recently, new light has been shed on the contributions of business associations to economic growth as well as on their internal capacities. Irwin, for example, examining the organizational capacity of business associations in three African countries (Kenya, Tanzania, and Ghana), argues that "supporting business associations in

1. An indicator of the density is "the proportion of the sector (or potential group) output produced by members" (Doner \& Schneider, 2000, p. 271). 
developing countries to influence public policy is increasingly seen as an important contributor to improving the business enabling environment, and as a consequence, to improving the vibrancy of the private sector leading, in turn, to more job creation and greater poverty alleviation" (2015, p.185), and Kuteesa and Mawejje (2016) assess the policy engagements of 21 business associations with the government of Uganda. In the Asian context, Unger and Chan $(2015 ; 1995)$ argue that China's control over business associations using state corporatist techniques is likely to persist in coming decades, due to the government's vigilance in warding off the possibility of members' influence and the success of societal corporatism historically, which is revealed by a comparison with the cases of other East Asian Tigers such as Japan, Taiwan, and South Korea.

Interestingly, although the literature commonly points out that business associations strengthen the relationship between government and businesses in Korea, they do not present detailed explanations of the activities and internal structures of them. Even researchers who devote more attention to business associations in Korea (Kim, 1997; Chu, 1994; Shin, 1991) do not provide detailed analysis of the resources at the disposal of the associations for carrying out their functions or their internal governance structures, which contribute to resolving conflicts of interest among their members and between businesses and government. Doner and Schneider (2000) analyze the functions and internal incentive structure of the Korean Federation of Textile Industries, but the depth of the analysis is limited because it is based on secondary sources. Furthermore, the federation doesn't appear to be a good case for understanding the roles of business associations in the Korean context considering the fact that it was not so powerful at the time of the study as other business associations such as KOAMI in the machinery industry and the Korean Electronic Industry Corporative in the electronics industry (Kim, 1997).

Why has the role of Korean business associations in the era of economic growth not been fully examined? We believe that it is because developmental state theorists have focused on professional "Weberian" public bureaucracy imbued with the ethos of "plan rationality" and centered on the chaebols (big businesses) that received subsidies and protection from the government (Chibber, 2002; Evans, 1995; Amsden, 1989). To the extent that reciprocity between the authoritarian government and the big businesses was viewed as a primary success factor in industrial development in Korea, the contributions of business associations were overlooked, and it was natural for developmental state theorists to see business associations as a secondary or auxiliary actor in the industrial policy process.

To correct this omission, we analyzed the functions of the KOAMI in the context of government-business relations. Following Doner and Schneider (2000), we divid- 
ed the KOAMI's functions into two categories: top-down functions relevant to implementing the policy programs delegated by the government and bottom-up functions related to providing information relevant to the industry. In addition, we examined the internal governance structure of the KOAMI to assess the extent to which its technological and policy expertise helped control rent seeking.

\section{INDUSTRIAL POLICY FOR DEVELOPING THE MACHINERY INDUSTRY IN KOREA}

\section{Background}

In the preamble to the "Six Pledges of the Revolution," a speech delivered immediately after the coup on May 16, 1961, Major General Park Chung-hee, disclosed that he would make the solving of economic problems the top priority. He regarded economic development and anticommunism as essential prerequisites to rebuilding the nation (Lee, 1999): "I want to reiterate that the essence of the revolution on May 16 is in the revolutionary industrialization of this country... Without rebuilding the national economy, we cannot defeat communists and we cannot stand on our own feet" (Park Chung-hee, 1963, p. 259). The machinery industry was highly valued because key industrial policy makers, including President Park as well as Kim Chung-yum and O Won-chol, strongly regarded the development of the machinery industry as critical to building a self-sustaining economy and to supporting the defense industry (Kim, 2006; O, 2006).

The industry was seen as the "mother industry" for industrialization with forward and backward linkages to the casting industry, the steel industry, and the shipbuilding industry. Moreover, the planned withdrawal of U.S. forces from South Korea as well as armed clashes with North Korea in the late 1960s led to heightened public awareness of the national security crisis, and the machinery industry was expected to play a key role in resolving the crisis by forming the foundation of the defense industry.

The historical experiences of Western Germany and Japan, which had achieved economic development and overcome circumstances similar to Korea, lent further support to the belief that developing the machinery industry was critical. When Park visited West Germany seeking a DM 200 million loan, the president and the economic ministers advised him that the construction of the autobahn and the development of the steel and machinery industries would make crucial contributions to national industrialization. According to a former head of the Korea Industrial Development Institute, who served as the translator during President Park's visit to West Germany, 
this advice and his experience in Germany made President Park determined to build an expressway and to establish steel, machinery, and automobile industries (interview with the former head of the Korea Industrial Development Institute and the former translator in President Park's visit to West Germany, February 15, 2012).

\section{The Development of Industrial Policy to Promote the Machinery Industry}

The recognition of the value of promoting the machinery industry stimulated the design of various programs in the early phase of Park's administration. However, industrial polices related to the machinery industry were not implemented in earnest until the second five-year economic development plan, when the government selected the machinery industry as one of the target industries, along with the steel industry and petrochemical industry. In 1967 the government enacted the Act for the Promotion of the Machinery Industry.

Based on this act, the Economy and Science Deliberation Council announced the seven- year master plan for the machinery industry. One goal was to achieve an average annual growth rate in the machinery industry of $21.7 \%$ by the seventh year, amounting $¥ 2.3$ billion, five times the amount in 1968. Another goal was to boost exports to USD\$651 million, six times the USD\$110 million of 1970 and to decrease dependence on imports from $62 \%$ in 1970 to $30 \%$ in 1976 . The plan also called for a more than $80 \%$ satisfaction rating with respect to the quality of domestic machinery and for a doubling of productivity.

Based on the seven-year master plan, the Ministry of Trade and Industry (MTI) announced three goals for the policy promoting the machinery industry: the promotion of localization, a switch from import substitution to export, and the establishment of a specialization and keiretsu system. To implementation these goals, the MTI introduced five policy directives: to increase the revolving fund, concentrate resources on the target, modernize facilities, innovate technology, and create demand. ${ }^{2}$

An array of policies was introduced to promote the industry as shown in table 1. The government institutionalized nonmonetary incentive tools like awarding a medal for the best export corporation, as well as offered financial incentive in the form of subsidies and special loans. In addition, certain industries were singled out for specialization and the firms in those industries designated to form a keiretsu. An industrial park for the machinery industry was constructed in the Changwon region. The corporations in the park were supported with funds to buy equipment.

2. These directives were laid out in an announcement made by the Ministry of Trade and Industry, on November 1, 1971. 
Table 1. Industrial Polices Promoting the Machinery Industry in Comparison with Policies Promoting Other Industries

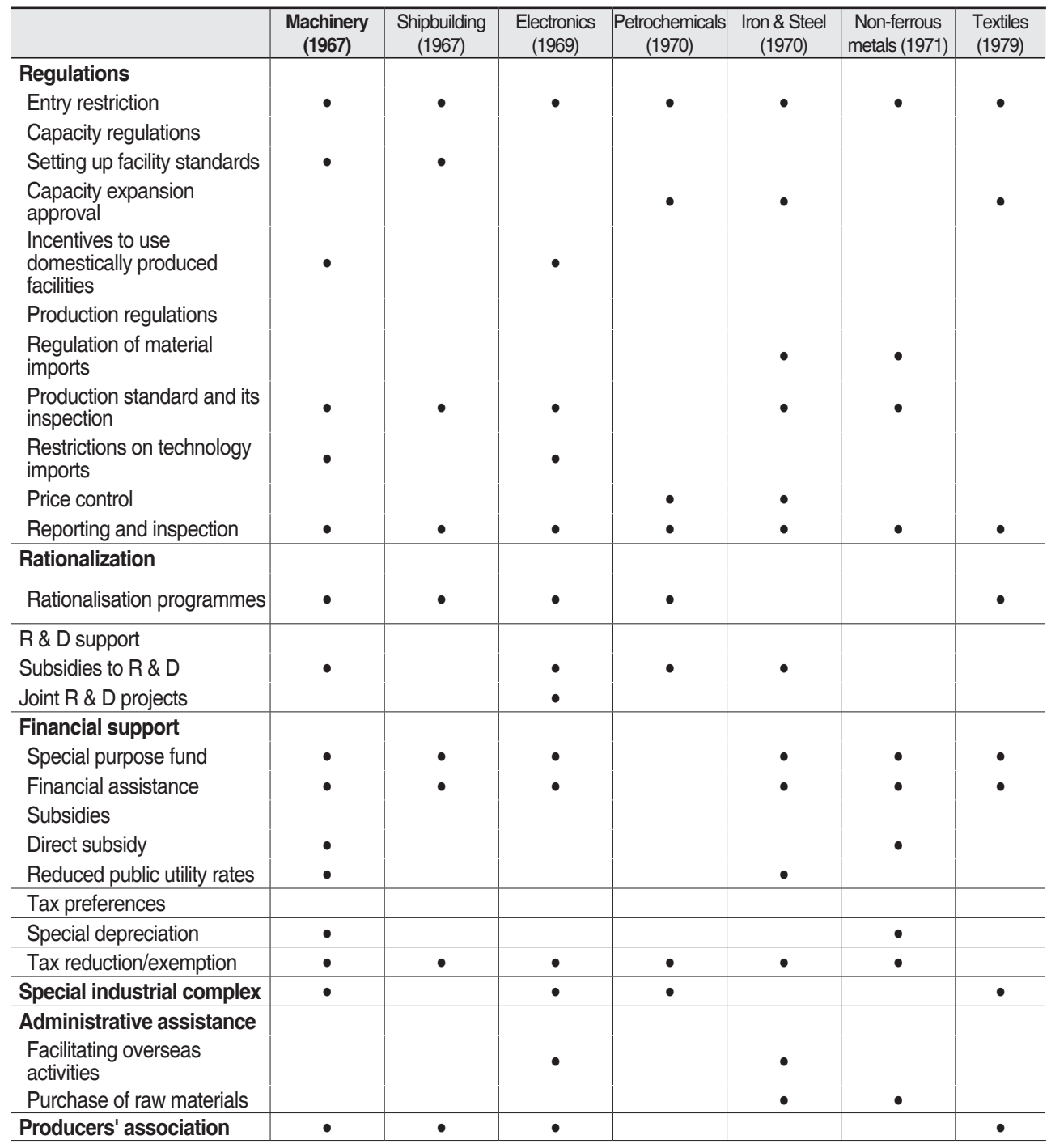

Source: Chang 1993.

\section{Development of the Machinery Industry}

Owing to the industrial policy supporting the machinery industry, it experienced rapid growth during the 1970 s, coming to represent a large part of the manufacturing industry overall, as illustrated in table 2 . In addition, after 1962, the growth rate of the 
machinery industry surpassed the average growth rate of the manufacturing industry, except during 1970 and 1972, as illustrated in table 3.

Table 2. Growth of the Machinery Industry in Korea, 1969-82

\begin{tabular}{c|c|c|c|c|c|c|c|c}
\hline \multirow{2}{*}{ Year } & \multicolumn{2}{|c|}{$\begin{array}{c}\text { Number of Employees } \\
\text { (Thousands) }\end{array}$} & \multicolumn{2}{|c|}{ Number of Firms } & \multicolumn{2}{|c|}{$\begin{array}{c}\text { Volume of Production } \\
\text { (billion \#) }\end{array}$} & \multicolumn{2}{|c}{$\begin{array}{c}\text { Volume of Value Added } \\
\text { (billion \#) }\end{array}$} \\
\cline { 2 - 9 } & $\begin{array}{c}\text { manufacturing } \\
\text { industry }\end{array}$ & $\begin{array}{c}\text { machinery } \\
\text { industry }\end{array}$ & $\begin{array}{c}\text { manufacturing } \\
\text { industry }\end{array}$ & $\begin{array}{c}\text { machinery } \\
\text { industry }\end{array}$ & $\begin{array}{c}\text { manufacturing } \\
\text { industry }\end{array}$ & $\begin{array}{c}\text { machinery } \\
\text { industry }\end{array}$ & $\begin{array}{c}\text { manufacturing } \\
\text { industry }\end{array}$ & $\begin{array}{c}\text { machinery } \\
\text { industry }\end{array}$ \\
\hline \multirow{2}{*}{1969} & 829 & 147 & 25,098 & 4,113 & 1,048 & 160 & 426 & 61 \\
& $(100.0)^{\star}$ & $(17.7)$ & $(100.0)$ & $(16.4)$ & $(100.0)$ & $(15.3)$ & $(100.0)$ & $(14.4)$ \\
\hline \multirow{2}{*}{1973} & 1,158 & 228 & 23,293 & 3,760 & 3,569 & 551 & 1,254 & 223 \\
& $(100.0)$ & $(19.7)$ & $(100.0)$ & $(16.1)$ & $(100.0)$ & $(15.4)$ & $(100.0)$ & $(17.8)$ \\
\hline 1982 & 2,101 & 563 & 37,212 & 8,596 & 51,631 & 11,617 & 17,312 & 4,380 \\
& $(100.0)$ & $(26.8)$ & $(100.0)$ & $(23.1)$ & $(100.0)$ & $(22.5)$ & $(100.0)$ & $(25.3)$ \\
\hline
\end{tabular}

* The number in parentheses is the percentage share of the industry.

Source: Korean Association of Machinery Industry 1969, 1973, 1982.

Table 3. Average Growth Rate by Industry Sector (\%), 1953-77*

\begin{tabular}{c|c|c|c|c|c|c|c|c}
\hline \multirow{2}{*}{ Period } & \multirow{2}{*}{$\begin{array}{c}\text { Whole } \\
\text { Industry }\end{array}$} & $\begin{array}{c}\text { Manufacturing } \\
\text { Industry }\end{array}$ & \multicolumn{7}{|c}{ Machinery Industry } \\
\cline { 5 - 9 } & & Averagef & $\begin{array}{c}\text { Metal } \\
\text { Materials }\end{array}$ & $\begin{array}{c}\text { General } \\
\text { Machinery }\end{array}$ & $\begin{array}{c}\text { Electrical } \\
\text { Instruments }\end{array}$ & $\begin{array}{c}\text { Trans- } \\
\text { portation } \\
\text { Machinery }\end{array}$ & $\begin{array}{c}\text { Precision } \\
\text { Instruments }\end{array}$ \\
\hline $1953-56$ & 3.8 & 21.7 & 20.6 & & & & & \\
\hline $1957-61$ & 4.7 & 7.9 & 14.7 & 17.0 & 14.4 & 16.7 & 12.7 & 9.6 \\
\hline $1962-69$ & 9.2 & 17.9 & 23.0 & 13.9 & 9.2 & 36.7 & 29.1 & 36.9 \\
\hline $1962-65$ & 6.6 & 11.6 & 17.9 & 13.6 & 11.3 & 34.1 & 19.3 & 27.4 \\
\hline $1966-69$ & 11.9 & 21.4 & 28.3 & 14.2 & 7.2 & 39.3 & 39.7 & 47.1 \\
\hline $1970-77$ & 10.3 & 19.6 & 23.9 & 20.1 & 15.1 & 34.1 & 15.9 & 31.8 \\
\hline $1970-72$ & 8.0 & 11.6 & 5.3 & 0.3 & 1.0 & 18.9 & -3.7 & 6.0 \\
\hline $1973-77$ & 11.7 & 24.6 & 36.6 & 33.8 & 24.5 & 44.1 & 29.4 & 50.2 \\
\hline
\end{tabular}

* Based on the Korean GDP published by the Bank of Korea in 1970 values.

$\dagger$ The data pertaining to precision instruments was calculated based on the index of industrial production of The Yearbook of Economic Statistics.

¥ The average growth rate in the machinery industry does not the rate of growth of the precision instruments business.

Source: Korea Association of Machinery Industry 1980, p. 158. 


\section{THE BUSINESS ASSOCIATION IN THE MACHINERY INDUSTRY}

\section{Functions of the Business Association in the Machinery Industry}

When the government started pushing industrial policy in earnest in the early 1960s, it also endeavored to enhance communication and cooperation with the private sector. President Park constantly emphasized the importance of partnership between the government and the private sector (Chosun Daily, December 22, 1970; Joongang Daily, December 27, 1971), and government leaders offered formal and informal opportunities for representatives of industry and businessmen in industrial policy to engage with the government, including through planning and major decision making, inviting them to attend, for example, the monthly export promotion meetings. ${ }^{3}$ Indeed, the government endeavored to institutionalize the private sector support system, which included professors who majored in machine engineering and business interest groups such as the Federation of Korean Industries (FKI) and the Korea Chamber of Commerce and Industry. ${ }^{4}$

3. According to a former minister of the Ministry of Finance and expert on industrial policy in Korea, the Councils for Policy Coordination were "arenas for exchange of opinions between public and private actors": "The Councils of Policy Coordination were managed in every sector by the Korea Development Institute (KDI). Officials, professors, journalists, and businessmen attended. They had discussions about the draft five-year plan, which the Economic Planning Bureau of the EPB circulated. In the process, public actors and private actors exchanged opinions, and journalists were provided with information about the direction and contents of industrial policy as well as the economic issues that the government was facing at that time. How useful the process was! In this way, the five-year plan evolved and the process of refining it became more important (interview with a former minister of MOF and expert on industrial policy in Korea, March 7, 2012)."

4. Moreover, businesspeople and the researchers in Japan and the United States were invited to participate government projects in the machinery industry. For example, a KoreanJapanese businessman was invited to give advice about how to best promote the machinery industry and how to manage complex machine factories in 1962. The government also entered into an agreement wherein domestic businessmen bought the facilities of a complex machine factory from a businessman in Japan with an international loan and under the warranty of the government. In addition, when the government undertook a project to construct core plants for the heavy machinery industry, including the casting industry, the special steel industry, and the shipbuilding industry, from 1969 to 1971, the EPB minister H. Y. Kim invited Dr. Harry Choi, who worked for Battelle Memorial Institute in the United States, to help. He became a member of the project team with researchers from the Korea Institute of Science and Technology and took the initiative to make the plans for the projects (Park, 2008). 
The KOAMI, however, was the most important external policy support system in the machinery industry. It was established in 1968 in order "to contribute to the promotion of the machinery industry and the development of the national economy by enhancing the rationalization of the machinery industry, increasing international cooperation, and pursuing reciprocal interests between machinery manufacturers." 5 A high-ranking official of the MTI recommended that businessmen in the industry establish associations for implementing quality assurance and warranty systems for domestic machines that were about to be introduced by the ministry. This paved the way for the establishment of the KOAMI. The KOAMI was the only business association in the field of the machinery industry that received an official approval from the ministry. It encompassed all kinds of firms in all kinds of subfields of the machinery industry. As shown in table 4, its membership increased dramatically in the period from its establishment in 1968 to 1981.

Table 4. Number of KOAMI Member Companies, 1968-81

\begin{tabular}{l|c|c|c|c|c|c}
\hline Year & 1968 & 1971 & 1972 & 1975 & 1980 & 1981 \\
\hline $\begin{array}{l}\text { Number of Member } \\
\text { Companies }\end{array}$ & 52 & 47 & 302 & 369 & 691 & 730 \\
\hline
\end{tabular}

Source: Korea Association of Machinery Industry 1989, p. 110.

KOAMI's activities included implementing the MTI's policy programs. For example, the ministry required machinery industry businesses to report on their imports, and then it rendered a judgment as to whether the machinery could be localized or not, at least in cases where the cost of the machinery exceeded a USD\$ 1 million. If this was deemed impossible, permission to import the machinery was given to the businesses. This regulation was aimed at decreasing the import of machinery and increasing the rate of localization. In this regulatory setting, the KOAMI took charge of not only judging whether the machinery could be localized, but also ensuring that the regulation prohibiting the importation of machinery made in foreign countries was adhered to. In addition, the MTI introduced the quality assurance and warranty systems in order to create a demand for domestic machinery. The KOAMI took on the responsibility of issuing certificates that verified product quality and that guaranteed repair when the machinery supplied by those under the domestic machinery purchasing fund was found to be defective during the warranty period. The figures pertaining to KOAMI's activities are shown in table 5.

5. KOAMI, article 1 of Articles of Association. 
Table 5. KOAMI Policy Programs, 1968-82

\begin{tabular}{|c|c|c|c|c|}
\hline \multirow{2}{*}{\multicolumn{2}{|c|}{ Activities }} & \multicolumn{3}{|c|}{ Periods } \\
\hline & & \multirow{2}{*}{$\begin{array}{c}1968-72 \\
2,536\end{array}$} & \multirow{2}{*}{$\begin{array}{c}1973-77 \\
4,523\end{array}$} & \multirow{2}{*}{$\begin{array}{c}\text { 1978-82 } \\
4,612\end{array}$} \\
\hline Warranty of Domestic & number of warranties* & & & \\
\hline Machinery's Quality & $\begin{array}{l}\text { amount of warranty } \\
\text { (million }\end{array}$ & 66,650 & 259,005 & 321,694 \\
\hline \multirow{2}{*}{$\begin{array}{l}\text { Reports on Machinery } \\
\text { Imports }\end{array}$} & $\begin{array}{l}\text { number of reports on machinery } \\
\text { imports } †\end{array}$ & - & 67 & 327 \\
\hline & $\begin{array}{l}\text { amount of machinery imports } \\
\text { (thousand US\$) }\end{array}$ & - & $2,147,254$ & $6,561,914$ \\
\hline \multirow{2}{*}{$\begin{array}{l}\text { Recommendations for } \\
\text { Machinery Imports }\end{array}$} & number of recommendations & - & 21,946 & 14,503 \\
\hline & $\begin{array}{l}\text { amount of imports recommendedł } \\
\text { (thousand US\$) }\end{array}$ & - & $1,116,081$ & 441,841 \\
\hline
\end{tabular}

* Issuance of machinery warranties was no longer required beginning in 1983.

† The first report on machinery imports was published in 1976.

¥ The data pertaining to the recommendations for machinery imports in 1978 and 1979 is omitted.

Source: Korean Association of Machinery Industry 1989.

Table 6. Composition of the Heavy Industry Practical Planning Group, 1977

\begin{tabular}{|c|c|c|c|}
\hline Supenvision & Chairperson & Coordinator & Members of the Group \\
\hline $\begin{array}{l}\text { Ministry of } \\
\text { Trade and } \\
\text { Industry }\end{array}$ & $\begin{array}{l}\text { Assistant } \\
\text { Minister } \\
\text { of Heavy } \\
\text { Industry of } \\
\text { Ministry of } \\
\text { Trade and } \\
\text { Industry }\end{array}$ & \begin{tabular}{|c|} 
\\
Eepartment 2 of the \\
Economic Planning \\
Board \\
Investment \\
\end{tabular} & $\begin{array}{l}\text {-Ministry of Trade and Industry: director of industrial planning, } \\
\text { director of heavy industry, director of mechanical industry, } \\
\text { director of chemical industry } \\
\text {-Ministry of Finance: director of financial systems, section chief of } \\
\text { tariff systems } \\
\text {-Ministry of Construction: director of industrial location } \\
\text {-Ministry of Science and Technology: director of human resources } \\
\text { planning, director of the heavy chemical planning group } \\
\text {-Korea Development Institute: senior researcher Y. H. Kim } \\
\text {-Korean Institute of Science and Technology: researchers K. T. } \\
\text { Jang, S. J. Yu } \\
\text {-Korea Development Bank: head of the investigations department } \\
\text {-Federation of Korean Industries: head of the investigations } \\
\text { department } \\
\text {-Korea Chamber of Commerce and Industry: head of the } \\
\text { investigations department } \\
\text {-Korea Association of the Machinery Industry Promotion: head of } \\
\text { the industry promotion department, director of planning for the } \\
\text { Precision Instruments Center } \\
\text {-Korea Maritime Research Institute: researcher D. S. Shin } \\
\text {-Korea Industrial Development Institute: Y. H. Baik (professor, } \\
\text { Choongang University) }\end{array}$ \\
\hline
\end{tabular}

Source: Economic Planning Board 1977. 
Another of KOAMI's activities related to providing information and data on businesses and markets in the machinery industry, and on technology trends and elucidating policy alternatives developed from the perspective of the businesses in the industry. For example, the KOAMI participated in developing the five-year plan. As shown in table 6, the representative of KOAMI participated in a heavy industry practical planning group for the plan with private experts from the Federation of Korean Industries, the Korea Chamber of Commerce and Industry, professors who majored in economics and engineering, and researchers from the national research institutes in the fields of the heavy industry and from national development banks.

The KOAMI carried out these bottom-up functions by submitting proposals for rules and regulations related to the industry or for the revision of rules, holding meetings with high-ranking government officials so it could air its opinions, setting up briefing sessions for businessmen about government policy directives and technology trends, carrying out statistical surveys on the status of the machinery industry, publishing policy research papers on current issues and the future direction of the promotion of the machinery industry, conducting international exchanges with research centers and firms, and holding exhibitions to show off domestic machinery and publishing periodicals.

For example, the KOAMI not only submitted sector-by-sector-planning of the machinery industry to the MTI but also conducted a survey regarding the current status of machinery industry businesses across the country over eight months in 1973. The survey gathered information ranging from the address and year of establishment of the company to financial statements, employment figures, production capacity, shipment capacity, raw materials requirements and intermediary goods, facilities, state of international cooperation, state of training, techniques, and so on (Korean Association of Machinery Industry, 1980, pp. 80-88). The reports on the results of the survey were submitted to the ministry. In addition, the KOAMI held meetings with major policy makers from the ministry, Economic Planning Board (EPB), the Ministry of Finance, and other related ministries and public agencies and expressed their opinions about policy and problems in the industrial setting. The KOAMI also drafted a law related to the machinery industry and submitted it to the ministry, according to a former head of the KOAMI promotion department (interview with a former head of the KOAMI Promotion Department, March 8, 2012). The records related to KOAMI's delivery of information and opinions cover the period from 1968 to 1982 and are shown in table 7. 
Table 7. KOAMl's Information Delivery, 1968-82

\begin{tabular}{l|c|c|c}
\hline \multirow{2}{*}{ Activities } & \multicolumn{3}{|c}{ Periods } \\
\cline { 2 - 4 } & $1968-72$ & $1973-77$ & $1978-82$ \\
\hline number of proposals submitted pertaining to industrial policy & 28 & 34 & 36 \\
\hline number of meetings held with high-ranking government officials & 3 & 13 & 10 \\
\hline $\begin{array}{l}\text { number of opening briefing sessions held for businessmen on } \\
\text { policy and technology }\end{array}$ & 22 & 36 & 66 \\
\hline $\begin{array}{l}\text { number of surveys on the machinery industry } \\
\text { number of policy research papers published on the promotion of } \\
\text { the machinery industry }\end{array}$ & 15 & 61 & 39 \\
\hline $\begin{array}{l}\text { number of international exchanges with research centers and firms } \\
\text { number of domestic machinery exhibitions and periodicals }\end{array}$ & 4 & 26 & 88 \\
\hline
\end{tabular}

Source: Korea Association of Machinery Industry 1989.

\section{Positive Effects and Incentive Structure}

The KOAMI's activities enhanced the implementation power of the Korean government, which had a relatively small-sized bureaucracy (Kim, 1991, p. 88; Woo-Cumings, 1995, pp. 452-453). Through intermediate organizations, such as the KOAMI, the Korean government possessed potent implementation power and the ability to penetrate society with a relatively small bureaucracy (Jung, 1997). Nevertheless, the KOAMI did not overpower the government because the government controlled the legal, financial and administrative resources that underpinned the KOAMI (Ha, 2006, p. 141). ${ }^{6}$

Government officials took advantage of the collaboration with the KOAMI to complement its own insufficient ability in implementing industrial policy, using the information provided by the association. Although government officials were all graduates of prestigious universities at that time, they had a lack of expertise with respect to industrial settings and machinery technologies. In particular, most of the public officials who passed the civil service examination had majored in law or social sciences and therefore lacked knowledge of engineering (Kwon, 2006, pp. 136-139). Under these circumstances, it was essential for public officials to procure information from outside sources in order to respond to the orders from senior policy makers, including the president and ministers (Jung, 1993, p. 73). Therefore, according to two former directors of the machinery industry and a former head of the KOAMI promotion

6. Therefore, Ha (2006, p. 141) describes the nature of the relationship between them as based on "top-down mutual dependence." 
department, MTI officials were willing to embrace new policy ideas and the expertise of intermediary organizations such as the KOAMI and the FKI (interviews with two former Director of the Machinery Industry of MTI and a former head of the KOAMI Promotion Department, March 7, 2012, September 25, 2012, March 8, 2012).

At the individual level, the officials and businessmen formed unofficial consultative groups and held irregular and unofficial meetings in private places. They used to share information in the cafeteria before work and work together in hotels after work (Ha, 2006, pp. 143-144). One former head of the investigations department of the FKI reported that "I informally had supported an official in the MTI. He was my university junior. He often called me to a hotel room and we stayed up two, three nights working. I couldn't let him alone in the room. We had very tough time" (interview with a former headman of Investigation Department of the FKI, February 14, 2012), while a former public official of the MTI stated that "I was not able to make a yearly supply and demand program. So, a public corporation had sent an employee, and we worked together all night. I was in the position of asking for help. I could not have completed the task without him" (interview with a former public official of the MTI, February 7, 2012).

The KOAMI also had an incentive to maintain a close relationship with the government. Above all, the KOAMI could obtain tangible and intangible benefits from its relationship with the government. For example, the government provided the KOAMI with a substantial amount of financial support when it contracted out several research and survey projects. Moreover, the regulation responsibilities delegated by the MTI gave the KOAMI authority over companies that tried to export machinery and prohibit imports. In addition, a former head of the KOAMI promotion department noted that it was expected that uncertainty in the machinery industry business environment would decrease as the government accepted the policy proposals of the KOAMI (interview with a former head of the KOAMI Promotion Department, March 8, 2012).

\section{Conditions for a Positive Effect}

The positive effects of the government-business relationship mediated through the KOAMI depended on a number of conditions. First, the KOAMI did not only depend on entrepreneurs in the industry in the course of procuring information, generating knowledge, and developing policy proposals. In conducting the survey and undertaking research for development strategy reports in 1978, for example, the KOAMI established a working group comprised of professors in Korea and in the U.S as well as executives and professionals working for Japanese machinery companies, government bureaucrats from the presidential secretariat, the EPB, MTI, the Ministry of Science 
and Technology, and other related ministries, researchers from the KDI and the Korea Advanced Institute of Science and Technology, and executives and the staff members of other business associations such as the FKI.

With these participants in the project, the KOAMI could reflect on and cross-check various opinions from different experts about policy proposals. Further, experts that were dispersed throughout various parts of the machinery industry could gather in one place. Thanks to the participation of these many parties, policy ideas originating from various sources were presented; the reports did not reflect the special interests of any particular party in the machinery industry but rather provided a broader and long-term perspective on the industry and technology, and so the government could trust that the information KOAMI produced was objective. And the diverse industry professionals who participated were strongly recommended and monitored by MTI officials, according to a former head of the KOAMI promotion department (interview with a former head of the KOAMI Promotion Department, March 8, 2012).

Second, the executive body of the KOAMI was a specialized functional organization; it was not just a simple consultative group of major entrepreneurs in the industry but a professional organization. As of 1980, KOAMI had 93 employees, and it had several departments including ones dedicated to policy, investigation, and technology, as well as an international office with a Tokyo branch. The executive body of the KOAMI was able not only to assume a long-term and broad-based perspective beyond the interests of an individual company but to coordinate the various stances of the government and individual companies. Furthermore, the executive body of the KOAMI could view matters from a neutral perspective. In addition, the staff members of the departments had autonomous power. The executive body of the KOAMI ensured that the he MTI's policies were carried out, and it also wielded technological and financial influence on the member companies because it took charge of managing the industry development fund.

This organizational structure and the executive body's autonomous power led staff members to assume a different attitude about policies designed to promote of the industry from that of employees of the machinery companies themselves. One of the former executives of the KOAMI whom we interviewed confessed that KOAMI staffers were occasionally confused as to whether they were employees of an interest group of the industry or public officials of the MTI. He remembered that the executives and the staff members of the KOAMI had frequently stood by the government's side and persuaded the corporations who were against the government, because they understood the stance held by the government. 


\section{CONCLUSION}

This article has examined a way the Korean developmental state created synergy between state and society to advance industrial development, namely, through business associations. The Korean government enforced interactions between the public and various private actors and networked with diverse private actors in the industry such as businessmen who owned companies, researchers in national research institutes, professionals in Japan and the United States as well as professors who majored in machinery engineering in U.S. universities. Additionally, the government promoted the organizing of business associations and institutionalized interactions with industry associations as a means of securing information and policy alternatives on the industry business as well as to enhance policy implementation capability with networks of private actors.

The government developed a close relationship with the professional staff members of the association, who had wider perspectives on the industry and were independent to an extent of business owners, and government officials also had formal and informal meetings with business owners in the industry. We maintain that the active role of business associations and the multiple ties they created with diverse private actors contributed to the Korean state's healthy embeddedness in society and business, which helped reduce special interests' rent-seeking behaviors and allowed government officials to formulate industrial policy from a broad and long-term perspective.

Our thesis challenges the statist view on the government-business relationship in Korea in the era of economic growth. Statists commonly emphasize the coercion the government used with the chaebols. Amsden (1989) argues that the Park Chung-hee government had five general controls at its disposal: control over and ownership of Korea's commercial banks, which provided the state with the means to orient the big businesses toward long-term economic activity; control over the number of firms allowed to receive protection and subsidies; control over prices, which curbed monopoly power; control over capital flight, which restricted rent seeking and capital diversification; and control over the lower classes, which were provided virtually no social services. With these tools, Amsden argues, the government served as the "primary decision maker," and the economic targets it suggested were "taken by businessmen as equivalent to compulsory orders" (Song, 1990, p. 91). Statists also maintain that the intermediate associations lacked power; Gereffi, for example, argues that "the link between the government and business groups in South Korea is quite direct. ... Vertical pressures cannot be easily countered, because intermediate or independent local institutions are weak, repressed, or absent" $(1990$, p. 97) in comparison with those of Latin American countries. 
Our research sheds new light on the functions of business associations and documents the specific mechanisms by which they contributed to economic growth in Korea and prevented rent seeking. Based on our findings, we argue that the diverse mechanisms use to create synergy between the state and society should be further examined in research related to Korean economic development from the perspective of state-society relations considering that industrial development requires the consent and the participation of various actors as well as active collaboration among powerful stakeholders in both the public and private sector (Eom, 2014; 2011; Pierre \& Peters, 2005: 6; Ahrens, 2002; Schneider, 1998; Aoki, Murdock, \& Masahiro, 1997; Evans, 1997; 1995).

The study, however, is not without limitations. Most of all, we cannot analyze the negative impact of the association. Even though the business associations functioned well as mediators as well as implementers of government programs, it also might have conducted various rent-seeking activities in the policy process. Considering the deep embeddedness of the Korean government in industry, it can be expected that the rent-seeking activities and "unhealthy" interaction between businesses and government might have been done in much more secretive ways than those in other developing countries. Therefore, the analysis of the rent-seeking activities of the business associations and its detrimental results on government industrial policy and economic development in Korea should be considered as a future research agenda.

\section{REFERENCES}

Ahrens, J. 2002. Governance and the implementation of technology policy in less developing countries. Economic of Innovation and New Technology, 11(4-5): 441-476.

Amsden, A. 1989. Asia's next giant. New York: Oxford University Press.

Aoki, M., Murdock, K., \& Okuno-Fujiwara, M. 1996. Beyond the East Asian miracle: Introducing the market-enhancing view. In M. Aoki, H.-K. Kim, \& M. Okuno-Fujiwara (eds.), The role of government in East Asian economic development: Comparative institutional analysis. Oxford: Oxford University Press.

Chang, H.-J. 1993. Political economy of industrial policy in Korea. Cambridge Journal of Economics, 17(2): 131-157.

Chibber, V. 2002. Bureaucratic rationality and the developmental state. American Journal of Sociology, 107(4): 951-989.

Chu, Y.-H. 1994. The state and development of the automobile industry in South 
Korea and Taiwan. In J. D. Aberbach (ed.), The role of the state in Taiwan's development. New York: M. E. Sharpe.

Coleman, W. D. 1988. Business and politics: A study of collective action. Montreal: McGill-Queen's University Press.

de Vroom, Bert. 1985. Quality regulation in the Dutch pharmaceutical industry: Conditions for private regulation by business interest associations. In W. Streeck \& P. C. Schmitter (eds.), Private interest government: Beyond market and state. London: Sage.

Doner, R. F. \& Schneider, B. R. 2000. Business associations and economic development: Why some associations contribute more than others. Business and Politics, 2(3): 261-288.

Eom, S.-J. 2011. Synergy between state and rural society for development: An analysis of the governance system of the rural saemaul undong in Korea. Korea Observer, 42(4): 583-620.

Eom, S.-J. 2014. The governance system of industrial policy in the era of growth in Korea from the perspective of state-society relations. Korean Journal of Policy Studies, 29(3): 1-30.

Evans, P. 1995. Embedded autonomy: States and industrial transformation. Princeton, NJ: Princeton University Press.

Evans, P. 1997. Development strategies across the public-private divide. In P. Evans (ed.), State-society synergy: Government and social capital in development. Berkeley: University of California Press.

Gereffi, G. 1990. Big business and the state. In G. Gereffi \& D. L. Wyman (eds.), Manufacturing miracles: Paths of industrialization in Latin America and East Asia. Princeton, NJ: Princeton University Press.

Ha, Y.-C. 2006. Late industrialization and the dynamics of the strong state in South Korea: Debureaucratization and hollowing out. Seoul: Seoul National University Press.

Irwin, D. 2015. Building the capacity of business associations in developing countries to influence public policy. Interest Groups and Advocacy, 4(2), 185-204.

Jung, J.-G. 1993. The president's economic leadership: The economic policy management of the Park Chung-hee, Chun Doo-hwan, and Rho Tae-woo administrations. Seoul: Korea Economy Newspaper Company.

Jung, Y.-D. 1997. Administrative reorganization in the strong state: The case of the Kim Young-Sam regime. In Y. H. Cho \& H. G. Frederickson (eds)., The White House and the Blue House: Government reform in the United States and Korea. Lanham, MD: University Press of America.

Korea Association of Machinery Industry (KOAMI). 1969, 1973, 1982. Yearbook of 
the machinery industry. Seoul: KOAMI.

Korea Association of Machinery Industry (KOAMI). 1980. 10th anniversary of the Korea Association of Machinery Industry. Seoul: KOAMI.

Korea Association of Machinery Industry (KOAMI). 1989. 20th anniversary of the Korea Association of Machinery Industry. Seoul: KOAMI.

Kim, C.-Y. 2006. From despair to hope: A memoir. Seoul: Randomhouse-Jungang.

Kim, K.-W. 1991. The Korean bureaucracy. Seoul: Daeyoung Moonhwasa.

Kim, S.-Y. 1997. Industrial policy and the role of business interest associations: Comparing the electronics industry and the textile industry. Korean Public Administration Review, 31(3): 73-88.

Kim, Y.-P. 1995. Uncertainty and the legitimacy of public policy. Seoul: Korea University Press.

Kuteesa, A., \& Mawejje, J. 2016. Between the market and the state: The capacity of business associations for policy engagement in Uganda. Journal of Modern African Studies, 54(4), 617-644.

Kwon, T.-J. 2006. Century-skipping industrialization and the democratization of Korea. Seoul: Nanam.

Lee, W.-B. 1999. The role of the United States in the five-year economic development plan, 1960-1965. In W.-B. Lee et al. (eds.), Political and Societal Change during the 1960s. New Understandings of Korean Modern History 10. Seoul: Baeksanseodang, 1999.

Lucas, J. 1997. The politics of business associations in the developing world. Journal of Developing Areas, 32(1): 71-96.

Marques, J. C. 2017. Industry business associations: Self-interested or socially conscious? Journal of Business Ethics, 143(4), 733-751.

Moore, M., \& Hamalai, L. 1993. Economic liberalization, political pluralism, and business associations in developing countries. World Development 21(12): $1895-1912$.

Nadvi, K. 1999. Facing the new competition: Business associations in developing country industrial clusters. Geneva: ILO/International Institute for Labor Studies.

O, W.-C. 2006. How Park Chung-hee created an economic power. Seoul: Dongsuh Press.

Olson, M. 1997. The new institutional economics. In C. Clague (ed.), Institutions and economic development. Baltimore, MD: Johns Hopkins University Press.

Park, C.-H. 1962. "Six pledges of the revolution”: Text of a Speech. Seoul: Dongsuh Press.

Park, C.-H. 1963. State, revolution, and me. Seoul: Hyangmoonsa. 
Park, Y. G. 2008. Process and character of the four core plant plan, 1969. Economic History, 44: 81-107.

Pierre, J., \& B. G. Peters. 2005. Governing complex societies: Trajectories and scenarios. New York: Palgrave Macmillan.

Schneider, B. R. 1998. Elusive synergy: Business-government relations and development. Comparative Politics, 31(1): 101-122.

Schneider, B. R. 2015. Designing industrial policy in Latin America. New York: Palgrave Macmillan.

Schneider, B. R., \& Maxfield, S. 1997. Business, the state, and economic performance in developing countries. In S. Maxfield \& B. R. Schneider (eds.), Business and the state in developing countries. Ithaca, NY: Cornell University Press.

Shin, R. W. 1991. The role of industrial policy agents: A study of Korean intermediate organization as a policy network. Pacific Focus 6(2): 49-64.

Shirley, M. M. 2005. Institutions and development. In C. Ménard \& M. M. Shirley (eds.), Handbook of new institutional economics. Dordrecht: Springer.

Song, B.-N. 1990. The rise of the Korean economy. Oxford University Press.

Streeck, W. 1982. Organizational consequence of neo-corporatist co-operation in West German labour unions. In G. Lehmbruch \& P. C. Schmitter (eds.), Patterns of corporatist policy-making. London: Sage.

Unger, J., \& Chan, A. 2015. State corporatism and business associations in China: A comparison with earlier emerging economies of East Asia. International Journal of Emerging Markets, 10(2), 178-193.

Unger, J. and Chan, A. 1995. China, corporatism, and the East Asian Model. The Australian Journal of Chinese Affairs, 33, 29-53.

Woo-Cumings, M. 1995. Developmental bureaucracy in comparative perspective: the evolution of the Korean civil service, in: J. Kim, M. Muramatsu, T. J. Pempel, \& K. Yamamura (eds.), The Japanese civil service and economic development. Oxford: Oxford University Press.

World Bank. 1993. The East Asian miracle: Economic growth and public policy. New York: Oxford University Press. 
